\title{
A Comparative Analysis of the Exchange Rate System of the BRICS
}

\author{
Meini Jiang \\ Jinan University, Guangzhou, China \\ Email:2861705032@qq.com
}

How to cite this paper: Jiang, M.N. (2019) A Comparative Analysis of the Exchange Rate System of the BRICS. Modern Economy, 10, 1168-1177.

https://doi.org/10.4236/me.2019.104079

Received: February 26, 2019

Accepted: April 7, 2019

Published: April 10, 2019

Copyright (C 2019 by author(s) and Scientific Research Publishing Inc. This work is licensed under the Creative Commons Attribution International License (CC BY 4.0).

http://creativecommons.org/licenses/by/4.0/

\section{(c) (i) Open Access}

\begin{abstract}
In the context of the gradual recovery of the US economy and the poor economic situation in Europe and Japan, the emerging economies are still experiencing rapid growth. The status of emerging economies represented by the BRICS countries on the global stage has been enhanced. The exchange rate, as the main system for foreign exchange of a country, has become a key issue affecting the stable economic development of the BRICS countries. This paper, adopting qualitative analysis, analyzes the development process of the exchange rate system of the BRICS countries, and compares the similarities and differences between the exchange rate regimes between them and the performance after the implementation of the new exchange rate regime. We can find that the choice of the exchange rate system shows that there is no difference between the exchange rate systems. An exchange rate system is suitable for one country, which means a good exchange rate system.
\end{abstract}

\section{Keywords}

BRICS Countries, Exchange Rate System, Comparison

\section{Introduction}

In 2001, Jim O'Neill, the former chief economist of Goldman Sachs, firstly proposed the concept of "BRIC". In October 2003, Goldman Sachs published a global economic report entitled "Dreaming With BRICs: The Path to 2050", predicting that the world economy will undergo a severe reshuffle by 2050, and the world's six new big economies will be China, the United States, India, Japan, Brazil and Russia. And the United Kingdom, Germany, France and Italy will be surpassed by this country.

In December 2010, South Africa was recruited as a full member to join the "BRICS" cooperation mechanism, and four member countries have become five 
member countries. The name is called the BRICS countries. According to the IMF, these countries have more than $40 \%$ of the world's population, accounting for nearly $30 \%$ of the world's land, and about $18.3 \%$ of global nominal output. In terms of nominal exchange rates, IMF reported that the GDP of China, Brazil, India and Russia in the BRICS countries have ranked among the top 10 in the world, respectively ranking $2^{\text {nd }}, 7^{\text {th }}, 9^{\text {th }}$ and $11^{\text {th }}$, and South Africa ranked $27^{\text {th }}$. In concrete terms, Brazil's gross national product ranks first in Latin America. As early as the 1960s and 1970s, Brazil has entered the ranks of sub-developed countries. More than 20 years ago, it had the basic conditions for becoming an economic big country. Russia is the world's largest natural gas exporter and the second largest oil exporter. According to Sohrabji (2009), India is the second most populous country in the world [1]. According to the government of the Indian, the Indian economy has grown steadily at an average annual rate of 5.6\% in the past 20 years. China's GDP surpassing Japan is in the second place since 2010. In 2013, National Bureau of Statistics reported that China's total import and export trade exceeded the historical threshold of 4 trillion US dollars for the first time, reaching US $\$ 4.16$ trillion. China replaced the United States as the world's largest trading nation. The Republic of South Africa is the largest economy in southern Africa and the window for the BRICS to further strengthen economic relations with southern African countries. The BRICS countries have different national conditions and different endowments. Countries choose different exchange rate systems based on their history, national conditions and goals. Qiang (2014) thinks that the establishment of the BRICS Development Bank on July 15, 2014 marked the beginning of the emerging economies to seek the right to speak in the international financial arena and enhance their financial soft power [2].

As for the evolution of the classification of exchange rate systems, IMF used the nominal classification method for the classification of exchange rate systems in various countries prior to 1999. Under this method, IMF divides the exchange rate system into three categories according to the officially announced exchange rate notice: pegged exchange rate system, limited elastic exchange rate system and large flexible exchange rate system. Since this classification method is relatively crude and cannot accurately reflect the real status of the international exchange rate system. So after 1999, IMF further began to divide the exchange rate system based on the size of the exchange rate elasticity of each country: no separate legal currency exchange rate, Bureau arrangements, traditional pegs, horizontal interval pegs, crawling pegs, crawling intervals, management floats, and independent floats. However, Jurgen et al. (2007) have views that with the changes in the international economic situation, the drawbacks of this classification method are also increasingly apparent [3]. On the one hand, there are large differences in the real exchange rate regimes of countries under the management floating category. If they are classified as one category in general, they violate the basic principle of avoiding ambiguity in the exchange rate system. On the other 
hand, the increasing efforts of central banks have also increased the difficulty of obtaining real data, making it increasingly difficult for IMF to define it accurately as one of the eight categories mentioned above. Therefore, in 2009 IMF announced the latest classification of the exchange rate system. Pattnai and $\mathrm{Mu}-$ neesh (2001) thinks this method not only cancels the crawling interval category in the original classification method, but also newly adds three kinds of exchange rate system: stable arrangements, class crawling arrangements and other management arrangements [4]. At the same time, according to more precise statistical standards, the new division method redefines management floats and independent floats, they are classified as floating and free-floating.

Specifically, according to IMF, we have the following classification. The stabilization arrangement is a kind of peg-to-peer arrangement, which means that the volatility of a country's spot market exchange rate is limited to $2 \%$ within 6 months or longer under the condition that exchange rate does not fluctuate. Once a country is classified as a stable arrangement, the country must not only maintain exchange rate stability, but also the exchange rate fluctuations. Michael (2008) thinks that the crawling arrangement refers to the exchange rate with a certain degree of volatility on the basis of the central exchange rate crawling, but the fluctuation range still does not exceed 2\% [5]. Moreover, the exchange rate fluctuations under the crawling arrangement are not less than $1 \%$ at the same time, which is considered to be the minimum limit of exchange rate fluctuations. Other management arrangements have the function of managing floats under the old method. The new taxonomy also distinguishes between floating and free floating: the exchange rate under the floating system is mostly determined by the market. Unless there is sufficient evidence to prove that the stability of the exchange rate at this stage is a non-governmental act. Otherwise the exchange rate volatility must break through the $2 \%$ limit mentioned in the stable arrangement and crawling arrangement. In the meantime, in order to prevent excessive exchange rate fluctuations, government authorities can intervene directly or indirectly. The free-floating system has stricter requirements on the exchange rate. $\mathrm{Yu}$ and Liu (2014) think that countries which are classified in this category can only intervene in the special case of market disorder within 6 months, and the number of interventions is less than 2 [6]. The number of days per intervention cannot exceed 3 days. The criteria for the classification of other systems in the new method are consistent with the 1998 classification. Under the new classification method, the difference between stable arrangement, class crawling, other management arrangements and floating, free floating is whether it is determined by the market, but the flexibility of the exchange rate system between them is not clearly defined.

Through the above analysis, we find that the elasticity of the stable arrangement in the new IMF classification method is between the traditional peg and the crawl peg in the former classification method, and it is somewhat similar to the traditional peg. The elasticity of the floating category is between independent 
floating and management floating, and is more inclined to manage floating. Free floating mostly belong to the original independent floating. Other management arrangements are seen a compromise between a floating exchange rate system and a fixed exchange rate system.

\section{The Evolution of the Exchange Rate System of the BRICS Countries}

According to the classification of IMF (2009), Brazil, India, and South Africa implement a free floating exchange rate system, while China and Russia implement a system of managing floating exchange rates [7].

According to Huang and Chen (2012), the exchange rate of the RMB can be roughly divided into five stages after the 1980s: 1) 1981-1984: China adopts a dual exchange rate system, and implements an internal settlement rate with quotas for foreign trade import and export commodities [8]. Other transactions still use official the exchange rate, in order to solve the problem of the excessive cost of changing exchanges in the foreign trade sector. Robert (2006) thought after that, the official exchange rate began to depreciate and closed to the internal settlement rate [9]. 2) From 1985 to 1993, the internal settlement price was abolished, and the foreign exchange settlement adopted a unified exchange rate. At the same time, the Chinese government began to implement an export-oriented policy to gradually devalue the renminbi. The RMB exchange rate was sharply depreciated from the 2.8 yuan at the beginning of 1985 to 8.7 yuan in 1994. 3) 1994-2004: In 1994, the monetary authorities officially claimed to adopt a floating exchange rate management mechanism, but the actual exchange rate system was pegged to the US dollar. During this period, Chinese economy has developed rapidly and steadily, the trade surplus has expanded year by year, and the pressure on the appreciation of the renminbi has been increasing. The central bank has to intervene on the market on a large scale in order to maintain a stable exchange rate. The result is that foreign exchange reserves have soared. As of 2004, National Bureau of Statistics reported that Chinese foreign exchange reserves soared to $30 \%$ of GDP. 4) 2005-2014: On July 21, 2005, China implemented the reform of the exchange rate system, which was transformed from a pegged US dollar to a managed floating exchange rate system based on market supply and demand. The channel for the appreciation of the renminbi has been started again. $\mathrm{Hu}$ (2009) estated in the all the appreciation of the renminbi against the US dollar is 2.1\% [10]. According to Frankel and Wei (2007), the Chinese exchange rate regime during this period was defined as a peg to a basket of currencies with almost all weights in the US dollar [11]. 5) From 2015 to the present: On August 11, 2015, the central bank announced the adjustment of the RMB-to-US dollar mid-price quotation mechanism and initiated various reforms including the mechanism. After the reform, the RMB exchange rate trend is closer to the market, guiding the market to form a reasonable expectation for the RMB exchange rate and continuing to promote the internationalization of 
the RMB.

Brazil is also a big country. The currency authorities in Brazil have long believed in "inflation-neutrality", which means inflation is not a problem as long as it does not affect supply and demand. Before 1990, there was not much attention paid to the inflation problem. The implementation of the exchange rate management method was to peg the US dollar and moderately underestimate way. Among them, in 1986, in order to deal with rapid internal inflation, Brazil tried to use a fixed exchange rate level for a long time, but did not succeed. During this time, inflation has been plaguing Brazil. During the period 1990-1994, the crawling and pegged exchange rate system was mainly adopted, accompanied by a certain nominal depreciation. The high trade surplus and the high inflation caused by capital inflows coexist in the time. From 1994 to 1999, Brazil began to use the US dollar as a nominal anchor and gradually stepped out of hyperinflation. In 1997, the current account deficit, stagnant growth and huge government debt put the currency of Brazil under depreciation pressure. In order to protect its crawling peg exchange rate system, the Brazilian government used foreign exchange reserves to avoid a sharp depreciation of its currency. Chen (1999) thinks this makes the Brazilian central bank has little policy space [12]. During the period 1996-1998, according to IMF, Brazil's foreign exchange reserves decreased by 24 billion US dollars, accounting for about $40 \%$ of the total reserves. Later, due to the serious imbalance in the balance of payments, the financial crisis hit Brazil serverly, and eventually the Brazilian government had to declare a transition from a substantial fixed exchange rate to a floating exchange rate system.

Before the 1980s, India implemented a nominal peg in the floating zone. The goal of the nominal exchange rate is to maintain a medium-term equilibrium of the real effective exchange rate. In the late 1980s, India's current account continued to deteriorate, with a three to four fold current account deficit in 10 years, while the currency of Indian faced enormous depreciation pressure. According to IMF the deficit of India's current account was about \$2 billion from 1980 to 1984. The current account deficit is unsustainable due to the tightening of short-term credit. Gerhaeusser (2010) thinks India's foreign exchange assets have fallen sharply, from $\$ 3.1$ billion in 1990 to $\$ 975$ million in July 1991 (even below the country's one-month import) [13]. In 1991, the currency of Indian faced tremendous depreciation pressure due to the continued increase in trade deficits and external debt. According to Lu and Chai (2011), due to the severe crisis in the national economy and the sharp deterioration of international debt, the Indian government launched the economic transformation reform of "liberalization, privatization and internationalization" [14]. In 1993, the Indian government fully adopted the exchange rate which reflects the supply and demand in the market. The Indian exchange rate management policy has three main objectives: to provide foreign exchange for the healthy development of the foreign exchange market when necessary; to maintain sufficient foreign exchange re- 
serves; to help eliminate the constraints in the foreign exchange market. At present, India's exchange rate system is a volatility management with no fixed exchange rate target, and at the same time allows the movement of exchange rate to be determined in an orderly manner by the market supply and demand situation. From the experience of India, Ding and Wang (2012) think it is very necessary to carefully adjust the pace and order of reform, opening of the external sector [15]. Under the floating exchange rate system, various guarantees on the stability of exchange rates should be avoided as much as possible. Economic individuals should be encouraged to use hedging instruments to manage the risks associated with exchange rate fluctuations.

After Russia became independent in 1991, it established the "Moscow Interbank Currency Exchange" and determined the official ruble exchange rate against the US dollar based on the foreign exchange transactions provided by the exchange. After Russia began to transform into a marketized economy in 1992, the full marketization of pricing was implemented, and the exchange rate was determined by the trading market. However, as the country has just become independent, national production is still in the recovery stage, and price liberalization has led to a rapid rise in price levels. Compared with the high domestic prices in Russia, the change in the exchange rate of the ruble is relatively small, making the price of imported goods relatively low. It hurts the competitiveness of the export sector and hurts the interests of domestic producers who import similar goods. At the same time, radical reforms have triggered economic recession and hyperinflation. Araki (2001) thinks this has greatly stimulated the demand for US dollars by domestic enterprises and residents [16]. The exchange rate fell sharply. In July 1995, the ruble exchange rate became 4553 rubles to 1 US dollar. In order to stabilize the ruble exchange rate, in July 1995, Russia began to implement the "foreign exchange corridor" system, which means exchange rate is no longer completely determined by the market supply and demand exchange rate, but the maximum and minimum range of the ruble against the dollar nominal exchange rate. This system continued until the beginning of 1998.

In 1998, the Russian government and the monetary authorities adopted a stricter policy of stabilizing the exchange rate. The Russian monetary authorities anchored the ruble exchange rate at 6.2 roubles to 1 US dollar and $15 \%$ of the two-way volatility, in order to stabilize domestic price levels. The program gives the central exchange rate, which is a more stringent peg. At the same time, the government announced the replacement of monetary units. According to Huang (2009), the ruble-denominated unit is reduced by a factor of 1000 , meaning that 1000 units of old rubles are equivalent to 1 unit of new rubles [17]. This behavior led to a currency crisis, because the government was unable to continue to stabilize the exchange rate, and on September 9, 1998, the government had to announce the abandonment of the target range and switched to a managed floating exchange rate system. In 2005, the Russian monetary authorities further libera- 
lized the exchange rate system, taking a dual-currency basket as a reference, and the volatility bandwidth was adjusted according to fundamental factors such as the balance of payments.

With the signing of the Bretton Woods Agreement in 1945, South Africa implemented a "stable but adjustable" exchange rate system that allowed its exchange rate adjustments to exceed a fixed marginal level only when there was an imbalance in the balance of payments. According to Foreign exchange administration, the exchange rate in South Africa has many features. Its exchange rate is determined to be 1 South African pound against 4.03 doller, or 3.5814 grams of gold. The South African pound at the time was completely pegged to the British pound. In February 1961, the South African currency unit was changed to South African Rand, the parity of the new currency unit against gold was set at 50\% of the original South African pound, and the South African pound against the US dollar was 1 rand: 1.4 US dollars which was maintained until 1971 October. In 1973, with the disintegration of the South African fixed exchange rate system, the South African Rand depreciated significantly by $12.3 \%$. From June 1974 to 1975, the South African monetary authorities adopted an "independent managed floating" exchange rate system. It was not until early 1979 that the South African authorities maintained the stability of the South African Rand against the US dollar for a considerable period of time.

In 1984, due to the apartheid policy of the South African government, the international community imposed financial sanctions on South Africa, forcing the Reserve Bank to re-intervene in the foreign exchange market. Accordingly, South Africa began to implement the dual-track exchange rate. However, after the 1992 multiparty elections, the government under President Nielsen Mandela once again initiated reforms of the foreign exchange market and exchange rate. In March 1993, South Africa abolished the "financial rand" and replaced the dual exchange rate system established in 1984 with a single exchange rate. The South African rand began to move towards a market-determined floating exchange rate system.

\section{Analysis of the Similarity and Difference of the Exchange Rate System in BRICS}

The BRICS countries have the same effect in the development of the exchange rate system. Basically, each country has undergone a change of fix exchange rate to a managed floating exchange rate system. I think there are three reasons why the BRICS countries have a relatively similar evolution of the exchange rate regime. Firstly it is needed within a country. As the fastest-growing countries in the emerging economies, the BRICS countries need to have more flexible and more market-compliant exchange rates to escort. The import and export business of enterprises or the national foreign exchange reserve management project need a more close to the marketized exchange rate system to manage the exchange rate changes of the country. Therefore, the managed floating exchange 
rate system can play a good role as a bridge between the single exchange rate system of a certain currency and the development of a free floating exchange rate system. Second, the international economic situation needs it. Take the change of Chinese exchange rate system as an example. What China implemented before 2005 was the exchange rate system pegged to the US dollar. Therefore, the exchange rate changes during this period is not obvious, and the low exchange rate makes Chinese exports continue to grow. But for countries like the United States that have been dealing with foreign trade in China, this situation is very unfavorable. Therefore, the United States will always quested that China manipulated the exchange rate in order to expand trade. A managed floating exchange rate system just solves this problem. More flexible exchange rate changes make manipulation of exchange rate can't stand on its heels. Thirdly financial globalization needs it. The exchange rate system has changed with the continuous improvement of the world financial system. Nowadays, world finance has achieved globalization, which requires an exchange rate that is closer to the needs of the market. As a model in emerging economies, the BRICS countries are at the forefront of the exchange rate system. Therefore, it is inevitable to change from a single exchange rate system that is pegged to a certain currency to a managed floating exchange rate.

Due to differences in national conditions and openness in the BRICS countries, the period of inflection point, the period of appreciation (devaluation) and the magnitude of each country's experience are different. In the late 1990s, China, India and South Africa first entered the depreciation channel, followed by Russia and Brazil. At the beginning of the $21^{\text {st }}$ century, due to the booming of the emerging market economy, the BRICS countries began to move away from the depreciation channel and showed an appreciation trend. This is related to the exchange rate system of each country, which is related to the development of the economy. Therefore in the final analysis, the choice and change of the exchange rate system of the BRICS countries are related to the economic development at home and abroad.

Of course, the BRICS countries also differ in their choice of exchange rate regime. First, the background and motivation of the exchange rate system are different. Due to internal economic imbalances and need to seek a more reasonable exchange rate system, both Russia and China decided to change exchange rate regime; India is due to a serious domestic fiscal deficit and needs to open its capital account; Brazil is facing a serious inflation crisis, while South Africa is Because of internal political factors. Second, some specific contents of the exchange rate system of BRICS are different. In the all, Brazil is a completely free floating exchange rate system, while the other four countries adopt a managed floating exchange rate system. Although the exchange rate regimes of the other four countries are the same, the specific content is different. India adopts an inflation targeting system that mainly controls domestic inflation; China mainly maintains stability with the US dollar exchange rate. Third, the performance of the 
BRICS countries after the exchange rate changes are also different. According to the initiative of changing the exchange rate system, BRICS countries can be divided into two categories. One type is forced, such as Russia, Brazil and South Africa. The other type is active, such as China and India.

\section{Conclusions}

From the above analysis, we can draw the following conclusions. First, the selection, change, and implementation of the BRICS exchange rate system are based on the country's economic structure, trade structure, international environment, and internal policies. Therefore, by comparing the differences in the choice of the exchange rate system between the BRICS countries and the performance after the implementation of the new exchange rate system, we can find that the choice of the exchange rate system fully shows that there is no difference between the exchange rate system. The country must choose a desirable exchange rate system based on the actual economic situation.

In summary, by comparing the evolution of the exchange rate system in the BRICS countries, we can learn from the experience and lessons of other countries in the reform of the exchange rate system, so that we can better improve China's exchange rate system. On the one hand, Chinese future exchange rate system will be more liberalized and closer to the market. In the process of RMB internationalization, exchange rate marketization is an indispensable step. On the other hand, it is necessary to effectively control the intensity and frequency of the central bank's intervention in the RMB exchange rate. Moderate intervention in the exchange rate is necessary, but too large or too frequent interventions can lead to more substantial changes in the exchange rate. The volatility of the RMB exchange rate has leverage and long-term influence. Therefore, every implementation of exchange rate intervention will have far-reaching effects, so we must be cautious.

\section{Conflicts of Interest}

The author declares no conflicts of interest regarding the publication of this paper.

\section{References}

[1] Sohrabji, N. (2009) Is India's Current Account Position Sustainable? SSRN Electronic Journal, No. 21, 26-45.

[2] Qiang, C. (2014) Comparative Analysis of Exchange Rate System in BRICS Countries. Times Financial Journal, No. 6, 109-110.

[3] von Hagen, J. and Zhou, J. (2007) The Choice of Exchange Regimes in Developing Countries: A Multinomial Panel Analysis. Journal of International Money and Finance, 26, 1071-1094. https://doi.org/10.1016/j.jimonfin.2007.05.006

[4] Pattnaik, S. and Kapur, M. (2001) Exchange Rate Regime? IMF Working Paper.

[5] Bleaneya, M. and Francisco, M. (2008) Balance Sheet Effects and the Choice of Exchange Rate Regime in Developing Countries. The Journal of International Trade 
and Economic Development, 17, 297-310.

https://doi.org/10.1080/09638190701872822

[6] Yu, D. and Liu, N. (2014) Analysis of the Choice and Effect of Exchange Rate System in BRICS Countries. Economic Management, 10, 1-10.

[7] IMF (2009) Global Financial Stability Report.

[8] Huang, W. and Chen, L. (2012) Research on the Evolution of the Exchange Rate System of the BRICS Countries and the Exchange Rate Performance of the BRICS Countries before and after the Crisis. World Economic Research, No. 4, 28-34.

[9] McKinnon, R. (2006) China's Exchange Rate Trap: Japan Redux?. American Economic Review, 96, 427-431. https://doi.org/10.1257/000282806777212459

[10] Hu, Y. (2009) China's Capital Account Opening: A 30 Years of Review and Reflection. Contemporary Finance \& Economics, No. 2, 41-47.

[11] Frankel, J.A. and Wei, S.J. (2007) Assessing Chinese Exchange Rate Regime. Economic Policy, 22, 575-627.

[12] Chen, C. (1999) The Brazilian Economy under the Impact of the East Asian Financial Crisis. Latin American Studies, No. 4, 15-19.

[13] Gerhaeusser, K, Iwasaki, Y. and Tulasidhar, V. (2010) Resurging Asian Giants: Lessons from the People's Republic of China and India. Asian Development Bank, Philippines.

[14] Lu, Q. and Chai, T. (2011) Reform of the Exchange Rate System in India and Its Enlightenment to China. International Finance Research, No. 5, 12-22.

[15] Ding, J. and Wang, J. (2002) China and India's Exploration and Comparison of Capital Projects. Shanghai World Economic Research, No. 1, 74-77.

[16] Araki, N. (2001) Exchange Rate Policy of Russia-Lessons to Learn from Russian Experiences. Economic and Social Research Institute.

[17] Huang, J. (2009) India's Capital Flow and Capital Account Opening. Financial Theory and Practice, No. 7, 105-110. 